\title{
Potential Role of Islamic Finance in Preventing Financial Crises: A Discourse Based on Three Financial Crises
}

\author{
Muhammad Imran Ejaz \\ Keynesion Institute of Management and Sciences(KIMS), Lahore Pakistan
}

\begin{abstract}
The Capitalist system has undergone numerous crises in its history. The Financial Crisis of 2007-2008 shook the International Financial architecture raising questions as to what was inherently wrong with the system. Islamic Finance offered solutions to the problems confronting the financial system. This study analyzes three crises; Black Wednesday 1992-the currency crisis that shook Britain; East Asian Currency Crisis and the Financial Crisis of 2007-2008. The causative factors of these crises have been isolated and studied under the light of Islamic Finance principles. This is a theoretical and analytical paper and is unique in analyzing the Black Wednesday Currency Crisis in the light of Islamic Finance principles. The study shows that the underlying causative factors of the three crises are in violation of the principles of Islamic Finance. The main causative factor behind the Currency Crises is shown to be the ability to carry out a Speculative attack which is possible due to the facility of short sales. The study shows that short sales are contrary to the teachings of Islamic Finance. Likewise, the role of speculation in the 2007-2008 crisis is also highlighted along with the other causative factors. The study concludes that if the causative factors isolated in the three crises, which are in violation of the rules of Islamic Jurisprudence and still persist in the system, are removed from the International Financial Architecture then this system would be given great stability and the chances of a further crisis would significantly diminish.
\end{abstract}

Keywords: Financial Crisis, Interest, Gharar, Speculation, reserves

\section{Introduction}

The Capitalist System has gone through numerous financial crises during the past two hundred years. One financial crisis follows another. This automatically leads to the question as to whether there is something inherently wrong with the Capitalist System. This question has begun to be asked with greater frequency and vigor after the Global Financial Crisis of 2007-2008.

Corresponding Author: Muhammad Imran Ejaz, e-mail: mohammad_imranejaz@hotmail.com

(c) COMSATS Institute of Information Technology Lahore, Pakistan. 
It has to be understood that this had not been the case before, especially right after the fall of Communism in the early 90's. The fall of Communism showed that Capitalism had won the war between the two economic systems. This had been due to the flaws within Communism but it did not necessarily mean that Capitalism was the best economic system that humanity had devised and lived under. The supporters of capitalism euphorically proclaimed that their system was the best that the world had seen. This claim was shattered with the occurrence of the Global Financial Crisis of 2007-2008. The next step was to look for a better system. The Muslims had been for a long time advocating the case of Islamic Finance but this time the difference was that even non-Muslim economists and intellectuals opened their eyes and began to take the Islamic Economic and Financial system seriously.

In order to come to conclusion as to the validity of the claim that if Islamic Financial Principles had been in place in the International Financial Architecture, the financial crises would not have precipitated, the researcher has attempted to carry out the following analysis and come to appropriate and relevant conclusions. First the researcher looks at the Currency crises in Britain in 1992, which is termed as Black Wednesday, and the East Asian crisis in 1997-1998.The mechanisms and the causative factors are studied with insight. The third crisis which has been studied is the financial crisis of 2007-2008 and a detailed study of its mechanism and causative factors is made. The researcher looks at these causative factors (of all the three crises) in the light of Islamic Finance. The researcher has attempted to come to a conclusion as to whether the three crises would have precipitated if Islamic Finance Principles had been in place. The possibility of a future crisis is determined on the basis of observing these causative factors in today's economy and of course after having determined if these causative factors are, in the first place, against the injunctions laid down in Islamic Finance or not.

A limitation of this study is that it is based on only three crises. Including more of the many crises that have taken place will make the research more conclusive.

\section{Mechanisms and Causative Factors of Black Wednesday (Britain-1992) and East Asian Currency Crisis}

\subsection{Black Wednesday}

Black Wednesday denotes the 16th of September 1992. On this day the government of the United Kingdom was compelled to pull out its currency, the pound sterling, from the European Exchange rate mechanism (ERM). A speculative attack was carried out on the pound sterling by George Soros who was a currency market investor. The British government was unable to maintain the exchange rate it had agreed to as member of the ERM. George Soros carried out short selling of the UK currency and generated a profit of more than one-billion-pound sterling for himself. In the process the loss to the 
UK was to the tune of approximately 3.4 billion pounds.

Budd, A. (2005) points out that initially, at the end of the seventies, the United Kingdom had refused to join the ERM. Despite not having joined, from the beginning of 1987 to early 1988 the UK's currency tracked the German Deutsche Mark and eventually joined the ERM in October 1990 and therefore the UK committed to keep the exchange rate of the pound with the other European countries within a 6\% deviation range (Budd, A. 2005).

In the 1990s the interest rates within Germany were very high and this caused tremendous difficulties for the countries of the ERM. The UK had further difficulties that it had a double deficit and the dollar was depreciating very quickly. As the exports of the UK were denominated in dollars so this was hurting the British. The fact that the British were about to lose their currency to a single European currency was an issue that hurt nationalistic pride within the UK. The UK was a member of the ERM and hence was not free to adjust its exchange rate as it wished. The UK was at the lower end of the ERM band and hence came under tremendous pressure from speculators in the foreign exchange market.

Some months before Black Wednesday the Hedge fund led by George Soros had been developing a tremendously massive short position in pounds sterling which would generate a huge profit for him if the pound depreciated out of the lower band dictated by the ERM. George Soros believed correctly that the position of the UK was not strong and its maintained exchange rate was not sustainable. The UK was exhausting its reserves to maintain its exchange rate and remain within the band set up by the ERM. The Prime Minister of the time John Major hiked up the interest rates to ten percent and billions in foreign currency reserves were depleted to purchase the pound sterling being sold in the foreign exchange market but all this was unsuccessful in keeping the exchange rate within the boundaries of the band set by the ERM.

Fratianni, M., \& Artis, M. J. (1996) write that on September 15th the hedge fund led by George Soros started to sell-off pounds sterling in great amounts. A requirement of the ERM was that the Central Bank of England was under obligation to receive any sale of pounds. The bank of England continuously purchased the pounds but this move was not sufficient as the Hedge Fund led by George Soros was flooding the market with pounds at a greater pace. The Bank of England raised the base interest rate from $10 \%$ to $12 \%$ so that the speculators may be more inclined to buy pounds but the foreign exchange dealers continued to sell the pound. Later in the evening the British government announced that it would be withdrawing from the ERM (Fratianni, M., \& Artis, M. J. 1996).

\subsection{The East Asian Currency Crisis}

This crisis involved much of East Asia and began in 1997. It generated fears that much of 
the world would be engulfed by it as a result of contagion. The crisis originated in Thailand when the Thai baht succumbed to speculative pressure and buckled down financially in the foreign exchange market. The government of Thailand was compelled to let the baht float as it did not have enough foreign currency reserves to successfully defend the exchange rate and hence the peg of the baht to the US dollar finished. With the spread of the crisis a lot of Southeast Asian countries along with Japan witnessed their currencies depreciating, the value of assets and stocks fell and debt levels tremendously increased. The other countries hit hard by the crisis included South Korea, Indonesia, Malaysia, and Philippines.

In the decade of the eighties these countries experienced very high growth rates and hence earned the title of Asian Tigers. This economic success went hand in hand with financial liberalization- the opening up of financial markets within these countries to capital flows. At the same time these countries pegged their currencies to the American dollar.

Traders in the currency markets were fully cognizant of the following facts: The foreign debt of Thailand which was in American dollars needed a huge demand for dollars. The foreign currency traders also held the view that at the current exchange rate of 25 baht being equal to 1 dollar the baht was overvalued. With this belief the Speculators jumped in. They began to sell the Baht short. The foreign currency dealers began to borrow the Thai Baht from the native banks and instantaneously traded them in the marketplace for foreign exchange in return for dollars. The belief was that eventually the baht would weaken enabling the currency dealers to buy them back at a lower price and hence earn a profit. In response to the situation the government of Thailand bought Bahts that were being dumped on the foreign exchange market and depleted its reserves to the extent of five billion US dollars. The Government also raised the interest rates from $10 \%$ to $12.5 \%$. But the Government of Thailand was lacking the American dollars to put up a fight against the speculative attack by the currency traders. Finally, on the second of July 1997, the Thai Government declared that it was allowing its currency to float and hence giving up the peg against the dollar. The Thai currency instantaneously shed 18\% of its value.

After the Thai Baht succumbed to the speculators, speculative attacks were carried out on the other East Asian currencies forcing them to abandon their pegs. This is described in finance as a regional contagion.

The Government of Hong Kong was unique in that it was able to defend its currency against the speculative attack. The reason behind this was the help of the Chinese who bought huge quantities of stock that were being retailed on the stock market in Hong Kong. The Chinese sold great quantities of American dollars in order to defend the 
Hong Kong Dollar and hence counter balanced the tremendous selling of Hong Kong dollars in the currency markets. The peg of the Hong Kong dollar to the US Dollar was defended with success.

In his book Mohamad, M. (2000) added that the foreign ministers of each of the ten countries that comprise ASEAN firmly held the view that the attack on their currencies (a well-synchronized handling of their currencies) was an intentional effort to weaken the economies of the ASEAN region. The Prime Minister of Malaysia Mahathir Muhammad blamed George Soros of ruination of the economy of Malaysia with immense currency speculation (Mohamad, M. 2000).

According to Mohamad, M. (2000), the prime minister of Malaysia, Mahathir Mohammad did not accept the help (financial assistance) of the IMF and the conditionalites that came along with it. Going against the recommendations of the IMF and its economists he imposed tight capital controls and pegged the ringgit to the US dollar at 3.8 ringgits for one dollar. Mahathir Mohammad had successfully isolated the mechanism according to which the speculative attack on Malaysia's currency was being carried out. He stopped the overseas trade in the Malaysian currency the ringgit and other ringgit assets and hence invalidating the offshore use of the ringgit. The amount of currency that local residents could take out of the country was imposed with limitations. These policies meant that sources of ringgit held overseas which speculators took on loan to influence the ringgit via selling short decreased and became limited. In case the ringgit was borrowed then the borrower had to buy back the limited ringgit at the increased price which was a very unappealing outlook (Mohamad, M. 2000).

It can be said that the essential precipitator of both the Currency crises (Black Wednesday and East Asian Crisis) was the ability to carry out speculative attacks.

As described above a speculative attack in the foreign exchange market involves the substantial sales of a nation's currency assets by the national and overseas financiers. A detailed analysis has been put forward earlier but what needs to be added here is the highlighting of the minute workings of a Speculative attack. A speculative attack involves short selling. Short selling is the practice of selling securities, other financial instruments and currencies that are not currently owned and subsequently repurchasing them. This is done in the hope and expectation by the seller that if the price falls then a profit will be earned. After short selling the currency, eventually, the exchange rate alters, and the speculator purchases the first currency once more; and now he receives a greater amount of it than before, and he returns the amount he had borrowed. Now the trader has more of the currency than the amount he had borrowed so a profit has been made. If the price of the currency had risen, then of course he would have made a loss. 


\section{The Financial Crisis of 2007-2008 (Mechanisms and Causative Factors)}

The financial crisis of 2007-2008, is given alternative names such as the Global Financial Crisis and 2008 financial crisis. This crisis is regarded by financial experts as the deepest and most harmful crisis ever since the Great Depression that took place in the 1930s. It endangered the precipitation of a complete breakdown of great economic organizations, which was stopped by the bailout of banks by state regimes, but stock markets fell internationally. The housing market was similarly hurt, ensuing in ejections, and foreclosures.

The housing bubble was at its largest size in 2006 but it burst in the United States of America resulting in the nose dive of the value of securities which were linked to the property market and as a result financial institutions within the world economy were hurt badly. The policies that resulted in the financial crisis had facilitated home ownership, supplied cheap and ready access to funds to be borrowed, overvaluation of subprime mortgages on the belief that property prices would go higher. World economies were hurt badly as a result and money could not be lent as easily as before which resulted in diminishing of world trade.

A lot of differing causes of the global crisis have been put forward. Some economists put forward that the main blame falls on high risk, complex financial products. Financial regulation was not in place and a failure of risk management was to blame as well. Undue borrowing, risky investments, and absence of transparency by economic organizations were causes that precipitated the crisis. Disintegrating mortgage-lending principles and the mortgage securitization channel, deregulation of derivatives, particularly credit default swaps, and the botches of credit rating organizations to appropriately price risk were other factors that can be held responsible. In 1999 the revoke of the Glass-Seagull Act effectually detached the difference between investment banks and depository banks in the U.S. This led to opening the door to the huge inflation in the numbers of the derivatives within the market. In the direct outcome of the financial crisis, calming fiscal and monetary policies were implemented to diminish the jolt to the economy. This expansionary monetary policy continues till today and has resulted in the world economies coming out of the recessions that they had fallen into for a number of years.

Attention by Stiglitz, J. E. (2009) is made to the fact that that the instantaneous origin of the crisis was the bursting of the property bubble in the U.S which as mentioned above was fullest in 2005-2006. Default rates on subprime and adjustable-rate mortgages (ARM) initiated to surge rapidly afterward. The initial rise in the prices of houses had been due to banks dishing out more loans to people who wanted to buy homes. Within the U.S, credit was easily available as a result of substantial inflow of capital from the world over as investors looked for safe havens after the Russian and East Asian financial 
crises. As banks began to give out more loans to potential home owners, housing prices began to rise. This caused a housing manufacturing explosion and made easy consumption, financed by borrowed money. Loans of several types (e.g., mortgage, automobile etc.) were easily available so consumers took an unparalleled debt burden (Stiglitz, J.E. 2009).

As component of the credit and housing booms, the quantity of financial contracts called mortgage-backed securities (MBS) and collateralized debt obligations (CDO), which derived their worth from mortgage outlays and housing costs, prominently amplified. These financial innovations permitted organizations and investors world over to put their investments in the housing market of the U.S. When housing prices started to fall, key international financial organizations who had borrowed and invested profoundly in subprime mortgages informed substantial financial damages.

Deteriorating prices meant that homes values became a lesser amount compared to the mortgage loan so that foreclosure became a financial possibility. This diminished the affluence of the consumers and wore away the monetary forte of banking establishments. Defaults and damages on the numerous other loan forms also enlarged ominously as the crisis extended from the housing market to different sections of the economy. The financial institutions had taken up substantial debt loads while giving the loans and lacked a financial base large enough to sustain the pressures of great loan defaults or mortgage backed securities losses. The losses that resulted compressed the capability of financial organizations to advance loans reducing the pace of economic motion. Worries concerning the stability of major monetary organizations forced central banks to give money to facilitate lending and bring back trust in the commercial paper market place as they play an important role in providing cash to commercial actions. Governments did bail out major financial organizations and brought into action economic stimulus policies, and in the process bearing more and greater monetary responsibilities.

The U.S. Financial Crisis Inquiry Commission described that the Federal Reserve's tragic inability to stop the surge of toxic mortgages; intense failures in corporate governance plus a lot of financial organizations performing irresponsibly and incurring inappropriately great amount of risk were factors to blame for the crisis.

In time, competition between lenders of mortgages for profits and market share developed, and when creditworthy borrowers were not available in sufficiently large amounts underwriting principles were loosened and the sale of riskier mortgages to borrowers who were not so creditworthy took place. Subprime lending in the U.S. extended intensely in the period of 2004-2006.

From the time period 1998 to 2006 the money value i.e. the price of an average house in 
the U.S. increased in value by $124 \%$. The housing bubble meant that the consumer attitude was such that a lot of the owners of the houses refinanced their houses at lower interest rates or further spending on other goods and services was financed by taking out second mortgages made possible by the increase in prices.

By September of 2008 the price of houses on average in the U.S. had fallen by more than $20 \%$ from their height in 2006 . When the prices were falling, debtors with adjustablerate mortgages were unable to refinance to circumvent the greater expenses connected with increasing interest rates and so started defaulting. In the year 2007, lenders started foreclosure actions on about 1.3 million possessions, a $79 \%$ escalation from the previous year. This amplified to 2.3 million in the year 2008 , an $81 \%$ escalation compared to the previous year i.e. 2007. In September 2009 the number of mortgages in the U.S. that were in foreclosure or delinquency had increased to $14.4 \%$.

Borrowing was stimulated and enhanced by the interest rates being lesser than in other years. Between the years 2000 and 2003, the Federal Reserve let fall the federal funds rate target from $6.5 \%$ to $1.0 \%$. The reason for this lowering of interest rate was to diminish the negative effects of the 2001 attacks on the twin towers along with the assumed threat of future deflation. Way back in 2002 it was obvious that credit was increasing housing investment instead of business. Quantitative scholarships using figures from progressive countries demonstrate that enhanced credit development played a large part in increasing the harshness of the 2008 global crisis.

Supplementary downward compression on interest rates was produced by the high and increasing current account deficit of the U.S., which in 2006 reached its highest at the same time as the housing bubble. The trade deficits made it necessary for the U.S. to take loans from the international market and this resulted in the prices of bonds going up and hence decreasing the interest rate

During the periods of 1996 and 2004, the current account deficit of the United States enlarged by $\$ 650$ billion. In order to fund these deficits, the U.S. had to take huge loans from the international markets which mainly included emerging economies in Asia and the oil producing nations which had large trade surpluses. The balance of payments accounts requires that a country with a large deficit in the current account should have a surplus in the capital account which means that huge amounts of money would and did flow into the U.S. to pay for imports. This inflow of funds materializes demand for different types of financial resources and hence raising their prices while depressing interest rates. Countries in the world such as China and the oil producing nations had the funds to lend to the Americans and this is what they did. Overseas governments delivered money by acquiring Treasury bonds and hence evaded a lot of the head on effect of the 2008 crisis. Consumers in the U.S. made use of the moneys taken on loan 
from the foreigners to increase consumption and buy property which bid up the housing bubble financial organizations advanced foreign moneys into mortgage-backed securities. The Federal Reserve Bank eventually increased the Fed funds rate dramatically from July 2004 to July 2006 . This resulted in the adjustable-rate mortgages rates to increase making them costlier for homeowners. This factor might have played a part in taking the air out of the housing bubble because asset prices are usually inversely proportional to the interest rate. When the bubble burst the value of the houses and the financial assets fell to a great degree.

Another contributing factor may have been the fact that the leverage ratios of the economy in general and the banks in particular increased tremendously in the period 2003-2007. This is called overleveraging and refers to the increased debt burden. Just before the crisis, the financial organizations had become highly leveraged and a large chunk of this leverage was obtained with the use of complex financial instruments such as derivatives which meant that regulators had a tough time trying to mitigate the financial organizations risk levels. These financial instruments were of such nature that once the crisis set in and bankruptcy took place it was extremely difficult to reorganize the financial organizations and they had to be bailed out by the governing authority of the country. The fact that U.S. financial organizations and households had become overleveraged before the crisis increased the risk they faced in case of the property bubble bursting and hence made the prospects for the economy bleaker.

The top five investment banks in the U.S. increased their leverage tremendously between the years 2004-2007. For the fiscal year 2007 these five organizations showed a debt to the tune of 4.1 trillion dollars. This meant that they were facing great exposure to risk in the case of a financial crisis and this is exactly what happened. Most of them had to be bailed out when the crisis struck.

As discussed above, financial innovation played a pivotal role in precipitating the crisis. The adjustable-rate mortgage-the mortgage backed securities-the collateralized debt obligations (CDO)-the Credit default swaps- these are examples of the products of financial engineering which have caused and aggravated the 2008 crisis. CDOs increased in amount from 20 billion dollars in 2004 to the height of 180 billion dollars in 2007 and then fell back to 20 billion dollars in 2008. Furthermore, the composition of CDOs changed with the component of subprime and non-prime mortgage debt having increased from $5 \%$ to $36 \%$ of the $\mathrm{CDO}$ assets. The rise in the quantity of these financially engineered products was accompanied by them increasing in complexity as well. Some particular financial products were designed such that regulations could be sidestepped. The mortgages which had the highest risk were created through the shadow banking system and it is believed that this competition from shadow banking may have forced the regular banking sector to decrease their underwriting standards leading to negative 
effects during the crisis. The markets for securitization that were under the umbrella of the shadow banking system almost shut down in the fall of 2008. Other economists have gone further and say that the financial crisis of 2008 is just a leaflet of the major crisis which is deeper and that there is a systemic crisis of capitalism itself. This suggests that there are economists who point towards deeper defects within capitalism.

Naked short selling: Another factor blamed for worsening the 2007-2008 crisis was the financiers taking huge short positions in weakening financial organizations like Morgan Stanley, Lehman Brothers and HBOS. This produced volatility in the stock market and put further downward compression on prices. In order to counter this move by the investors a lot of nations announced regulations constraining short selling. Naked short selling involves short-selling an asset such as stock without firstly borrowing the financial asset or making sure that the financial asset can be loaned out. This action was generally constrained. When the crisis started, the Securities and Exchange Commission in the US stepped in and in September 2008 short sales mainly in financial stocks was prohibited to protect the firms in turmoil in the stock exchange. This prohibition was eventually lifted some weeks afterwards as the regulators believed that the ruling was not calming the stock prices. Similar bans were introduced world over and regulators generally held the view that short selling caused prices of stocks of the firms in financial turmoil to fall.

\section{The Causative Factors studied from the Perspective of Islamic Finance - A Prescription to Prevent a Financial Crisis 4.1 Speculation}

As has been highlighted, speculation played a significant part in precipitating the currency crises in Britain and in East Asia. In fact, as was pointed out, speculation played a part in aggravating the 2008 financial crisis.

It is pointed out by Usmani, J. M. M. T. (2010) that if speculation is limited to only trade in goods and services i.e. to real trade, then it will not cause harm to society. A merchant who engages in every kind of trade that he sees to be profitable and leaves that trade when he finds that it will result in loss- if he deals in cotton one day and mangoes the next-is carrying out speculation. This type of speculation is not harmful for the economy and Islam does not prohibit such trade as long as hoarding is not done. If the trader when he makes this speculative activity makes a mistake then he will only harm himself and not the system but if we take the example of the financial speculator, we see that his wrongful decisions can cause harm to the entire economic system. This results as the financial speculator does not engage in trade of real goods and services. Trade essentially involves the transfer by a person of his ownership of a good or service to a second person in return for a consideration (price received). Transfer of ownership is crucial here. This obviously implies that a person cannot sell what he does not own. This can be inferred by logic but more importantly this is a requirement of Islamic law. 
The Prophet Muhammad has said, "Do not sell what you do not have."

The Prophet Muhammad has also commanded that a person cannot sell something unless he has it in his possession.

The transfer of risk is important. As the risk of the commodity that is sold is not transferred to the buyer except if he has taken its physical or constructive possession so the purchaser cannot trade it to the third party except if he has attained its delivery in a physical or in a constructive way, for example via his agent or a deed that gives him complete command on the commodity traded (Usmani, J. M. M. T. 2010).

\subsection{Short Sales}

Mufti Taqi Usmani continues to explain in Usmani, J. M. M. T. (2010) that most of the speculative sales that are done nowadays are done without ownership. Short sales are major in the markets for speculation and for the reason mentioned in the previous sentence their dealings cannot be described as real trade. The Speculative attacks that are carried out involve hedge funds taking massive short positions using short sales. Another feature of real trade is that the purchaser genuinely desires that the goods bought should be handed over to him whether it is for his consumption or to be sold further to someone. However, in speculative dealings, the handing over of the goods is never done. The speculative transaction is not done with the aim of taking the good into possession. The speculators are only interested in making a profit by continuously buying and selling which means that the system is more like gambling and less like trade and commerce. This feature of speculation is which creates the predicament for the economy. If speculation was cleared of short sales then it would not have contributed to the crises that have been discussed (Usmani, J. M. M. T. 2010).

\subsection{Sale of Debts}

A true sale involves the handover of the good from the seller to the purchaser; therefore, it is rational that the seller must have total command on the good being sold to be handed over to the buyer. If the transfer of the good sold to the purchaser is in anyway doubtful, although the goods are in the ownership of the seller, even then this would mean that the purchaser is being cheated and misled. The sale of debt is likewise deception as the risk of default is being transferred to the buyer as there is a chance that the original debtor may not pay up to the person buying the debt. This is one of the reasons why the sale of debt is disallowed in Islam. The second reason is that within the economy debt is usually sold at a discount. This has the constituent of interest which is barred in Islam. The sale of debts was a conspicuous factor that caused the 2008 crisis.

\subsection{Transparency}

An essential component of easy and unhindered trade is transparency. This is emphasized by Islamic Law. The two sides in a trade dealing must be fully aware of what 
they are about to do. The purchaser has to know what he is about to purchase and the seller should be fully aware of the price he will get in return and when he will get it. If a good is enfolded in a package and the insides are unidentified to the purchaser, then the sale of this commodity is not valid. This is the verdict even if the purchaser has decided to take a gamble by purchasing it.

Trades deficient in essential transparency are categorized in Islamic jurisprudence as 'Gharar' and the Holy Prophet Muhammad has forbidden such transactions very clearly. If a product is faulty, the trader is under compulsion to reveal it to the purchaser.

The Holy Prophet Muhammad has said: "Whoever sells a defective commodity without disclosing it remains in Allah's wrath"

According to Usmani, J. M. M. T. (2010) numerous dealings in financial marketplaces are not transparent as they are too intricate to be completely comprehended by a lot of participants. They are also barely understood by financial professionals. George Soros, the financier who had the expertise to precipitate the currency crises in Britain and East Asia declared his inability to understand all of them and said that some of the derivatives are so intricate that the risk they involve cannot be comprehended even by the most capable financier (Usmani, J. M. M. T. 2010). In the previous pages the researcher has shown that derivatives played a fundamental role in causing the 2008 crisis. An elimination of these un-Islamic factors from the financial system is essential to prevent any further crises. It has to be recognized that transparency is not just a requirement of Shariah but is also held to be essential according to non-Islamic principles.

\section{Conclusion and Recommendations}

In isolating the causative factors in the mechanisms of the three crises (Black Wednesday-Britain 1992; East Asian Crisis 1997-1998; and the Financial Crisis of 20072008) the common factor has been the ability of players to carry out a Speculative attack. This Speculative attack has been the primary factor in the first two crises which are Currency crises. In the Financial Crisis of 2007-2008, the speculative moves on the stocks of the large financial institutions in trouble was not the originating factor of the crisis but a problem that had to be tackled by the regulators as it was aggravating the crisis. The problem was tackled and short sales which were instrumental in the speculative positioning were banned by the leading countries such as the US, Britain, Australia and others. The speculative attack was causing the prices of stocks in the major and troubled financial institutions to fall. Hence, as the researcher has shown in the thesis, Speculation did play a negative role in the 2007-2008 crisis. 
However, the speculative attack in the first two crises mentioned (Black Wednesday and East Asian Crisis) was the major causative factor responsible for precipitating the crisis. The researcher has shown that these speculative attacks would not have been possible if the principles of Islamic Finance had been in place. Speculative attacks are only possible because the speculators have the facility of short sales available to them. The researcher has shown that short sales are contrary to Shariah as they involve the sale of currencies or stock which are not in the ownership of the seller-the speculator in this case. Shariah has forbidden the sale of that thing which is not in the ownership and possession of the seller.

In the 2007-2008 Financial Crisis a major fault lay with the sub-prime mortgages and their packaging into CDOs (Collateralized Debt Obligations). These CDOs were then sold in the financial markets. When the housing bubble burst, this pyramid of CDOs collapsed bringing down with them large financial institutions which had invested in them. Islam has forbidden the sale of debt and these CDOs would never have been created and sold if the Principles of Islamic Finance had been in place.

Islam has stressed that transparency must be present in all transactions if they are to be valid. The absence of transparency, where the buyer and seller are unaware fully of the nature of the transaction, makes the contract invalid and in the terminology of Islamic Jurisprudence this lack of transparency leads to Gharar (Uncertainty). The element of Gharar was tremendous in the 2007-2008 crisis as derivatives, such as futures, options and swaps, which caused the crisis and resulted in wiping out $45 \%$ of the world's wealth are strictly forbidden in Islam because they contain Gharar. Even the most sophisticated investor and financier is unable to comprehend and assess the financial risk in these derivatives and hence Gharar exists in them.

Briefly, it should be added here that the problem with the International Financial System began with the legalization of Interest-this led to the creation of paper money; the fractional reserve banking system; the further sale of debt and then the creation of derivatives. All this financial innovation has been possible because of the legalization of interest and all to earn money by the controllers of world finance who are only a handful compared to the total population of this globe.

The researcher has clearly shown that none of these three crises would have materialized if the Principles of Islamic Finance had been in place.

The question now arises is whether the next crisis is going to take place or not. A conclusion can be drawn by analyzing if the causative factors isolated by the researcher in this thesis, which as seen are contrary to Islamic teachings, still exist in the World economy. The answer: Short sales still prevail and with it the possibility of speculative attacks. Debt continues to be sold. Financial engineering is creating more complex debt 
to be sold such as 'synthetic' CDOs (issued by Goldman Sachs just recently) but of course the volume of CDOs is much less than it was just before the crisis (it was 320 billion dollars' worth before the crisis of 2008 and approximately 100 billion dollars in 2014 according to the Financial Times). Derivatives still dominate the sky line of the world economy. The value of the derivatives market is approximately 710 trillion dollars which is $20 \%$ greater than its level just before the 2008 crisis. What has happened to the interest based debt in the economy? The answer is that the policy the Western countries used to come out of the recession that followed the 2007-2008 crisis has been called Quantitative easing and this of course has just been increasing the money supply. This money supply has increased by the creation of more debt which of course is Interest based. The factors which caused the crisis as the researcher has shown have multiplied or still exist to a certain extent since the last crisis studied so the answer is very obvious that in order to prevent the next crisis the Principles of Islamic Finance will have to be adopted. This would be a radical move given the current financial system but drastic steps will have to be taken if another crisis is to be prevented.

Islam is a viable code of life because it presents an alternative to the flaws that exist in the methods and ways devised by those who do not realize the significance of Divine Guidance. In this regard, great work has been done by Islamic scholars in presenting Islamic financing modes as alternatives to the rate of Interest. Great effort and commitment is needed to eventually totally remove Interest from the International financial architecture. With the rate of interest all the financial contracts which are in violation of Shariah will also have to be removed from the scene of global finance. The initial steps have been taken but the journey is very long and difficult.

\section{References}

Budd, A. (2005). Black Wednesday-A Re-examination of Britain's Experience in the Exchange Rate Mechanism. IEA Occasional Paper(135).

Chapra, M. U. (2009). The Global Financial Crisis : Can Islamic Finance Help ? Issues in International Financial Crisis from an Islamic Perspective. Jeddah: Islamic Economic Research Center King Abdul Aziz University.

Fratianni, M., \& Artis, M. J. (1996). The lira and the pound in the 1992 currency crisis: Fundamentals or speculation? The Collapse of Exchange Rate Regimes (pp. 143159): Springer.

Mohamad, M. (2000). The Malaysian Currency Crisis How and why it happened: Pelanduk Publications.

Stiglitz, J. E. (2009). The financial crisis of 2007-2008 and its macroeconomic consequences.

Usmani, D. M. I. A. U. (2002). Meezan Bank's Guide to Islamic Banking. Karachi: Dar ul 
Ishaat.

Usmani, M. M. T. (1998). an Introduction to Islamic Finance. Faisalabad: Maktaba Al Arafi.

Usmani, J. M. M. T. (2010). Present Financial Crisis : Causes and Remedies from an Islamic Perspective. Paper presented at the World Economic Forum, Davos. 